\title{
Extreme Hypoxia Decreases the Adherence of Granulocytes to Endothelial Cells in Vitro ${ }^{a}$
}

\author{
ANNEKE PIETERSMA, NETTY DE JONG, \\ JOHAN F. KOSTER, AND WIM SLUITER \\ Department of Biochemistry \\ Candiovascular Research Institute \\ Enasmus University \\ PO Bax 1738 \\ 3000 DR Rotterdam, The Netherlands
}

\section{INTRODUCTION}

Mild hypoxia $\left(\mathrm{pO}_{2}=53 \mathrm{~mm} \mathrm{Hg}\right)$ has been shown to increase the adherence properties of human umbilical vein endothelial cells (HUVEC). ${ }^{1}$ Since the oxygen tension in the ischemic heart can decrease to values far below $53 \mathrm{~mm} \mathrm{^{2 }}$ we have studied the effect of extreme hypoxia $\left(\mathrm{pO}_{2}=7.5 \mathrm{~mm} \mathrm{Hg}\right)$ on the adherence properties of HUVEC monolayers.

\section{RESULTS AND DISCUSSION}

Exposure of HUVEC to extreme hypoxia for a short period of $30 \mathrm{~min}$ had no significant effect on the adherence properties of these cells (FIG. 1). When the duration of hypoxia was increased to $2 \mathrm{~h}$ the adherence of PMN significantly $(p<0.02)$ decreased to about $50 \%$ of the normoxic control (FIG. 1). The decreased adherence was not due to a functional impairment of the PMN. ${ }^{3}$ This suggested that hypoxia directly affects the endothelial cells. Since the viability of these cells did not decrease, the present finding could possibly be due to an increased generation of anti-adhesive factors or a decreased basal expression of leukocyte endothelial cell adhesion molecules. Neither of these possibilities was found to be true. ${ }^{4}$

The present results seem paradoxical to the in vino situation where marginating granulocytes are suspect of mediating some of the early consequences (e.g., edema) of ischemia. However, when we stimulated HUVEC with lipopolysaccharide (LPS, 0.1 $\mu \mathrm{g} / \mathrm{ml}$ ) during the $2 \mathrm{~h}$ period of hypoxia, PMN adherence increased fivefold. Stimulation of HUVEC with LPS under normoxic conditions increased the adherence of PMN only two- to threefold, but because of a higher basal adherence the number

\footnotetext{
a This work supported by Grant no. 89.226 from the Netherlands Heart Foundation.
} 


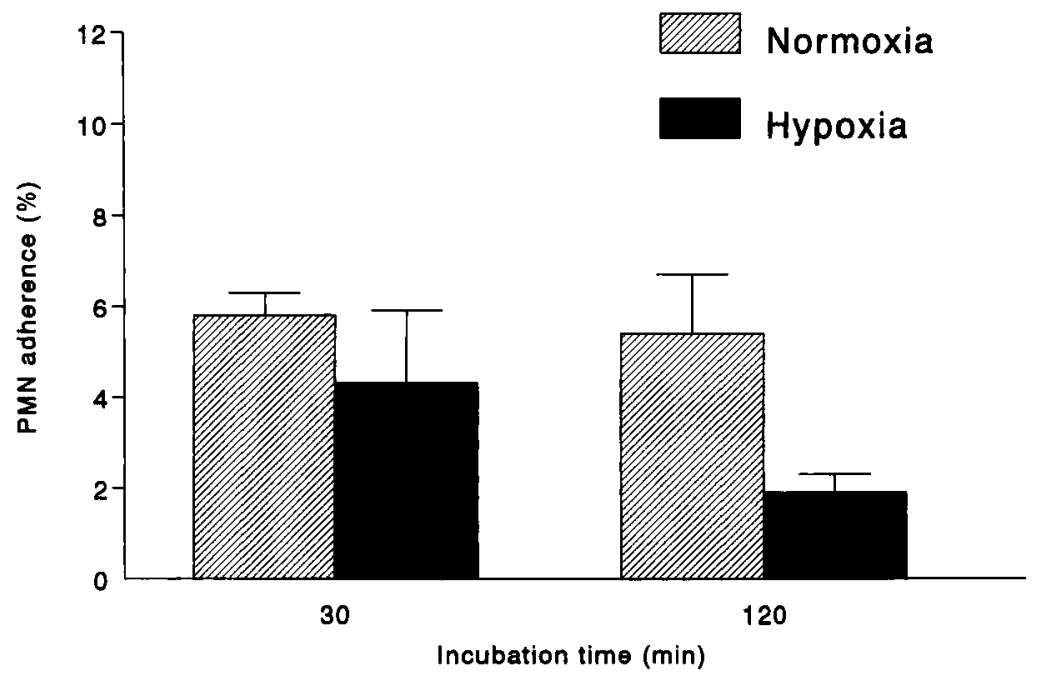

FIGURE 1. Effect of hypoxia on the adherence properties of HUVEC. Confluent monolayers of HUVEC, isolated and cultured as described previously, ${ }^{4}$ were exposed to hypoxia for $30 \mathrm{~min}$ or $2 \mathrm{~h}$ at $37^{\circ} \mathrm{C}$. Next, PMN were added and their adherence to HUVEC assessed within $\mathrm{l} \mathrm{h}$ of continuous hypoxia in a hypoxic incubator chamber. ${ }^{3}$ The adherence of PMN to HUVEC significantly $(p<0.02)$ decreased after $2 \mathrm{~h}$, but not after $30 \mathrm{~min}$ of hypoxia.

of PMN that adhered to activated normoxic HUVEC, i.e., $36 \times 10^{3} \pm 2.5 \times 10^{3}$ $\mathrm{PMN} / \mathrm{cm}^{2}$, was the same as under hypoxic conditions.

Taken together these findings show that endothelial cells under extreme hypoxia become less adhesive for PMN but remain sensitive to stimulation. This indicates that an additional stimulus is needed to trigger the increased margination of PMN in the ischemic heart.

\section{REFERENCES}

1. Milhoan, K. A., T. A. Lane \& C. M. Bloor. 1992. Am. J. Physiol. (Heart Circ. Physiol. 32) 263: H956-H962.

2. Shibano, T. \& Y. A Aiko. 1983. Arch. Int. Pharmacodyn. 264: 274-286.

3. Pietersma, A., N. De Jong, J. F. Koster \& W. Sluiter. 1992. Mol. Cell. Biochem. 116: 197-202.

4. Pietersma, A., N. de Jong, J. F. Koster \& W. Sluiter. Am. J. Physiol. (Heart Circ. Physiol.) In press. 